\title{
Sin brors vokter
}

«Den enkelte har aldrig med et andet menneske at gøre uden at han holder noget af dets liv i sin hånd. Det kan være meget lidt, en forbigående stemning, en oplagthed, man får til at visne, eller som man vækker, en lede man uddyber eller hæver. Men det kan også være forfærdende meget, så det simpelthen står til den enkelte, om den andens liv lykkes eller ej.»

Det går plutselig opp for meg at de stillferdige kineserne ved bordet i hjørnet ikke er gjester.

- Er du klar over at vi har sittet her i snart seks timer? Geir Sverre Braut ser spørrende på meg med ett og et kvart øye. Han skal ikke hjem for kvelden. I Oslo bor han på en særdeles enkel hybel - «den skulle du nesten sett» - «hjemme» er Bryne på Jæren. Derimot skal han med første morgenfly til undervisningsoppdrag i Stavanger.

Hjemreisene var en del av kontrakten da han ble ansatt i Helsetilsynet. «Flyr gratis på statens regning,» slo VG opp over to helsider i 2006. Saken falt imidlertid sammen allerede etter ingressen. «Han var den soleklart beste søkeren vi hadde til stillingen, samtidig som det var klart at han måtte få dekket hjemreiser dersom han skulle jobbe i Oslo,» sa helsedirektør Lars E. Hanssen til avisen, «... og jeg har ikke angret et sekund. Han har gjort en strålende jobb.» Lederen i LO Stat toppet det hele ved å si (riktignok med syrlig undertekst) at «denne mannen må ha en helt unik kompetanse». Etterpå fikk Geir Sverre Braut tekstmelding fra en misunnelig venn: «Gratulerer med $\mathrm{CV}$, fotografi og jobbattest over to helsider i landets største løssalgsavis. Fikk du det også gratis?»

Jeg får ikke se hybelen. Neste formiddag tikker det inn e-post fra intervjuobjektet: «eg nådde førelesinga med 20 minutts margin på mi side, så det var perfekt. Og førelesinga blei ein «höjdare», som svensken ville ha sagt. Forsamlinga (og eg) var i storform. Då det var slutt, fortsette debatten så det suste.» Samtidig som den opplagte representanten for tilsynet kan notere seg for nok en glitrende innertier, går intervjueren inn til skivebom. Min nye «digital voice recorder» har fått med seg åtte minutter og tre sekunder av gårsdagens maratonsamtale. O ironi! Fire minutter av opptaket er dessuten forhandlinger mellom Geir Sverre Braut og en i overkant omsorgsfull servitør.

- Jeg skulle ha bestilt sterk, slår han fast over sin pang-pang-biff medium. Man er ikke vant til å forhandle i Helsetilsynet.

\section{En postmoderne emissær}

Når tilsynets direktør berømmer sin nestkommanderende, er det ikke minst Geir Sverre Brauts talent som formidler - jeg hadde nær skrevet formilder - det siktes til. Rollene er viselig fordelt slik at han har utadrettet virksomhet som en sentral arbeidsoppgave. Kanskje ville det ha blitt for mye å ha ham innendørs på heltid? Han praktiserer det sjefen kaller «leading by running»«opp og ned trappene og minst én gang om dagen til sjokoladebutikken, mannen går på raske karbohydrater». På kontoret har han engler $i$ taket og egen antenne for kortbølgeradio. Modellhelikopter er blitt observert i korridoren. Ute påtreffes Geir Sverre Braut i rute mellom sør, nord, øst og vest, til arenaer der faglig forsvarlighet og profesjonsetikk står på dagsordenen. Han ytrer seg presist, engasjert og alltid forberedt. Budskapet hans om «godt nok» har fungert inspirerende og inkluderende, han er ønsket velkommen inn og trenger knapt banke på. Det er en ikke liten bragd for et statlig tilsynsorgan som ifølge ham selv har verdensrekord $\mathrm{i}$ å frata helsearbeidere autorisasjonen.

\section{- Sikter du mot toppen?}

- Titler er helt uinteressant. Nestleder passer meg godt. Lars (E. Hanssen, min anmerkning) tar støyten når det stormer som verst. Jeg kan gjerne stå i nærheten når det smeller, men vil helst unngå å skyte av meg fingrene. Egentlig hadde jeg lyst til å bli pato$\log$. Jeg er en nysgjerrig observatør, analytisk av natur, har anlegg for å se og gjenkjenne mønstre. Helsetilsynet er en unik utkikkspost og gir tilgang til et stort kontaktnett.

\section{Det vi ikke tør snakke om}

«Två sanningar närmar sig varann. En kommer inifrån, en kommer utifrån, och där de möts har man en chans att få se sig själv,» heter det i et dikt av Tomas Tranströmer. Helsetilsynet har mandat til å kikke oss i kortene, særlig dem vi fors $ø$ ker å holde tett til brystet.

- Hva er det verste?

- Helsepersonell som utnytter, ikke respekterer eller rett og slett ikke forstår pasientens sårbarhet. Faglige feil er mye sjeldnere grunnlag for alvorlige reaksjoner fra tilsynet. Når vi tar autorisasjonen fra folk, handler det oftest om rus, seksuelle relasjoner eller tyveri fra pasientene. Alle som vedkjenner seg følelsene sine, vil gjenkjenne forbudte impulser og avgrunner i seg selv. Poenget er hvordan vi håndterer dem. Profesjonalitet er mer enn faglighet. Det du ikke tør snakke med kollegaen din om, er trolig ikke profesjonelt.

- Det er blitt et mantra at man lærer av sine feil. Men er vi tjent med nervøse leger som er så redde for å gjøre feil at de systematisk overdiagnostiserer og overbehandler?

- I Norge er fagmiljøene gitt mye tillit i forvaltning av forsvarlighet og kvalitet. Tillit må besvares med tilsvarende selvjustis. En ivrig og åpen fagkultur er det viktigste verktøyet, den kan aldri erstattes av et detaljert regelverk eller faglige retningslinjer. En av mine tidlige læremestre var Dagfinn Moe, administrerende overlege og kirurg da jeg var turnuslege ved Farsund sykehus. Han viste oss hvor det skjøre balansepunktet mellom for mye og for lite ligger i praksis. Samtalene med ham før, under og etter undersøkelser og operasjoner var uvurderlige bilder på hvordan et levende mikrofellesskap er avgjørende for å stabilisere den medisinske atferden til hver enkelt av oss på et fornuftig nivå. Han greide å formidle faglig interesse kombinert med respekt for den enkelte pasient helt uten teori. Kall det gjerne livsveisetikk - hvordan man møter dilemmaer med frimodighet og trygghet rotfestet i det levde profesjonelle livet.

Krenkelser av sårbare enkeltindivider og grupper kan også være institusjonelle og legitimert fra sentralt hold. Geir Sverre Braut er opptatt av etikken rundt meticillinresistente Staphylococcus aureus (MRSA).

- MRSA rammer ikke bare sterke grupper, men like gjerne gamle med kognitiv svikt på tampen av livet. I motsetning til hiv-/aidspasientene har ikke disse noen lobbyister som lager bråk på deres vegne. Ofte blir de smittede isolert nederst i gangen på sykehjemmet med instruks om at betjening og pårørende skal kle seg i grønt eller gult før de går inn. Så blir de 


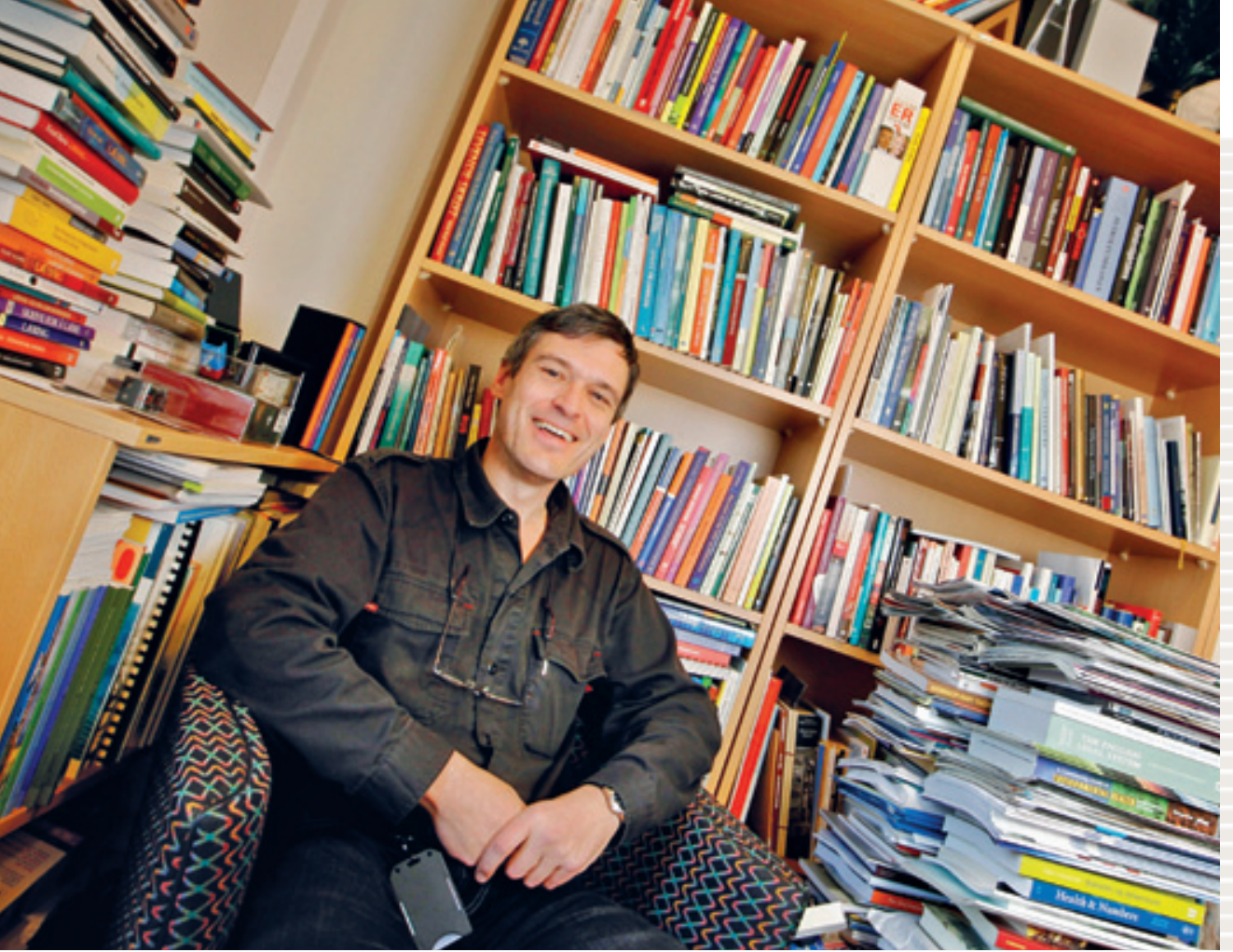

fratatt Jærbladet på grunn av smittefrykt. Man skal pinadø ha gode smittevernargumenter for å forsvare slike angrep på integritet, sårbarhet og selvbestemmelse.

\section{Bjelken i ditt eget øye}

- Hva ville du vært mest engstelig for hvis du skulle gått tilbake til klinisk praksis i dag?

- Det samme jeg frykter som assisterende direktør - at jeg i tankeløshet eller arrogant hybris skal tråkke på andre mennesker. Vi driver ikke blålysmedisin i tilsynet, men det er emosjonelt utfordrende likevel. I møte med de enkelte sakene tenker jeg iblant «hvordan er det mulig?», men også «dette kunne vært meg».

I Bergprekenen advarer Jesus disiplene mot å fordømme: «Splinten i din brors øye ser du, men bjelken i ditt eget øye blir du ikke var.» Geir Sverre Braut ble akutt var bjelken 7. desember 1963. Han sto ved siden av en jevnaldrende kamerat som svingte rundt med en pinne. Pinnen brakk, og ytterleddet penetrerete Geir Sverre Brauts venstre øye med stor kraft.

- Uflaks. Jeg bebreider ingen. Snarere vil jeg berømme øyelegen som henviste meg til en privatpraktiserende kollega. Derfor slapp jeg glassøye. Flere leger burde henvise lateralt for en supplerende vurdering.

Det skadede øyet tilfører hans vennlige fremtoning en dimensjon av noe utolkbart og svakt foruroligende. Et klart konkurransefortrinn i enkelte situasjoner, men ikke alle. I 1980-årene jobbet han et års tid ved Rogaland psykiatriske sykehus.

- Du kan jo tenke deg hvordan det virket på psykotiske pasienter når jeg pekte på det høyre øyet mitt og sa: «Du skal se i dette når du snakker med meg, ikke i det andre.»

\section{Omvendelse er humbug}

Fra 1992 til 1997 var Geir Sverre Braut en produktiv redaktør av det allmennog samfunnsmedisinske bladet Utposten.
Der presenterte han seg selv: «Røykjer ikkje, nedsett syn på venstre auget, barnlaus, trur på Gud, elles god allmenntilstand og takksam for nåden.» Han har fortsatt sans for skillet mellom profesjonelt, personlig og privat. Vi enes eksempelvis om at nakenbilde av statsråd med motorsag gjør seg dårlig på Skavlan. Samtidig forstår Geir Sverre Braut at hans personlige verdigrunnlag er relevant for offentligheten, selv om han presiserer at Helsetilsynet er et kontrollorgan som jobber «nedstrøms»" i forhold til verdier og normer satt av det norske fellesskapet.

- Jeg er oppvokst på Klepp. Slektsgården ligger der, men far hadde ikke beste odel. Foreldrene mine var jernbanefolk og sosialister. - Og gudstroen, er den medfødt eller tilkjempet?

Filosofen og teologen K.E. Løgstrup sier et sted at «omvendelse er humbug». Det guddommelige og Jesus har på et vis alltid vært med meg. Jeg ser ikke alternativet og har aldri følt behov for å gjøre

- Hva er synd?

- $\AA$ tro er å gjøre det levelig for seg selv. Å synde er å gjøre det ulevelig for andre. I mitt eget liv angrer jeg mest på det jeg ikke har gjort, og da mener jeg ikke selvrealisering. Jeg skulle vært mer til stede når noen har trengt meg.

Geir Sverre Braut prøvde å bli katolikk, men forble lutheraner. Det ble umulig for ham å forsone seg med pavemakten, pontifikatet!

\section{LA6BNA}

Som det flogvitet han trolig var, fikk vesle Geir Sverre holde på med sitt. Man skal ikke se bort fra at han i dagens klima kunne ha blitt «fanget opp», som det heter. I stedet har han liksom skummet fløten av de barnepsykiatriske atferdsdiagnosene - rastløst vitebegjær, ubendig virketrang, ekstrem fokuseringsevne og uforstyrrelig målretopprør mot troen.

\section{Geir Sverre Braut}

\author{
Født i Stavanger 1955
}

- Cand.med. Universitetet i Oslo 1980

- Diplom i folkehelsekunnskap fra Nordiska hälsovårdshögskolan, Göteborg, 1991

- Spesialist i samfunnsmedisin 1997

- Fylkeslege i Rogaland 1994-2002

- Assisterende direktør i Statens helsetilsyn fra 2002

- Førstelektor ved Høgskolen Stord/ Haugesund fra 2002

Foto Håkon Mosvold Larsen/SCANPIX

tethet. Han snakker og skriver esperanto, har lært seg nytestamentlig gresk og er aktiv radioamatør med identiteten LA6BNA.

- I helgen skal jeg prøve meg $\mathrm{i}$ en konkurranse på gammeldags radioteleks, sånn som de brukte i skipskommunikasjonen fra 1960 til rundt 2000.

Et barn som får holde på med sitt, går selvsagt glipp av noe.

- De glemte å lære meg å svømme. Jeg sto i hjørnet av skolens basseng sammen med en kompis og hadde det kjekt. Som voksen mann var det ikke fullt så kjekt å plaske rundt blant andres unger. «Er han pedofil?» En badevakt på Nordtvet bad her i Oslo så meg og spurte ganske enkelt: «Kan du ikke svømme?» Etter to timer kunne jeg det. Jeg kunne forgylt den dama!

- Hva heter «ribbe, pinnekjøtt, øl og dram» på esperanto?

- Ripajo, lignera viando, biero kaj glaseto. Lignera viando har jeg aldri sett brukt, så det er bare en ren oversettelse av «kjøtt med pinnepreg eller -påvirkning». Glaseto betyr egentlig lite glass, men blir brukt allegorisk om en liten «pinne» med rusbringende væske.

Geir Sverre Braut er glad i dikt. John Donne er blant favorittene. Jeg kvitterer takknemlig for samtalen, nærværet og innsynet $\mathrm{i}$ helseforvaltningens irrganger.

And now good morrow to our waking souls, Which watch not one another out of fear; For love, all love of other sights controls, And makes one little room, an everywhere. Let sea-discoverers to new worlds have gone, Let maps to other, worlds on worlds have shown,

Let us possess one world, each hath one, and is one.

John Donne

Elisabeth Swensen

elswense@online.no

Tidsskriftet 